\title{
PENGELOLAAN EKOSISTEM GAMBUT SEBAGAI UPAYA MITIGASI PERUBAHAN IKLIM DI PROVINSI KALIMANTAN SELATAN
}

\author{
Agus Sarwo Edy Sudrajat ${ }^{1}$ \\ Sri Subekti \\ Program Studi Perencanaan Wilayah dan Kota Universitas Semarang ${ }^{1}$ \\ Jurusan Teknik Lingkungan Fakultas Teknik Universitas Pandanaran ${ }^{2}$ \\ Penulis Korespondensi e-mail: agus.sarwo16@gmail.com
}

\section{ABSTRACK}

Peat ecosystems are one of the potential natural resources that are very rich in biodiversity. Global warming is a process of increasing the temperature of the earth. One of the effects of global warming is changing climate characterized by changes in temperature and rainfall. One of the impacts of this is the occurrence of peatland fires, especially in the dry season. Based on this, it is necessary to do management of peatlands as an effort to mitigate climate change and maintain unspoiled peatland areas. Result from this text is knowing how to manage peat ecosystem on South Kalimantan, so if the peat ecosystem can be protect and then the climate be controlled.

Keywords: Peatlands, Mitigation, Management, Climate Change

\begin{abstract}
ABSTRAK
Ekosistem gambut menjadi salah satu potensi sumber daya alam yang melimpah dengan keanekaragaman hayati. Pemanasan global disebut juga sebagai suatu proses kenaikan temperature di bumi, dimana efek dari pemanasan global ini yaitu perubahan iklim dengan ditandai adanya perubahan suhu dan curah hujan. Salah satu dampak dari hal tersebut adalah terjadinya kebakaran lahan gambut khususnya pada musim kemarau. Berdasarkan hal tersebut, maka perlu dilakukannya pengelolaan ekosistem lahan gambut sebagai upaya untuk mitigasi perubahan iklim dan mempertahankan areal lahan gambut yang masih alami. Hasil akhir dari tulisan ini adalah mengetahui cara pengelolaan ekosistem gambut di Kalimantan Selatan, sehingga apabila ekosistem gambut terjaga maka perubahan iklim dapat dikendalikan.

Kata Kunci: Lahan Gambut, Mitigasi, Pengelolaan, Perubahan Iklim
\end{abstract}


Jurnal Planologi Vol. 16, No. 2, Oktober 2019

Available : http://jurnal.unissula.ac.id/index.php/psa

\section{PENDAHULUAN}

Peran dan fungsi lahan gambut sangat penting bagi keberlangsungan kehidupan semua makhluk hidup baik manusia maupun flora dan fauna. Hal ini dikarenakan lahan gambut berfungsi sebagai penjaga perubahan iklim global. Lahan gambut jika telah mengalami kerusakan, maka sulit untuk dikembalikan ke kondisi lahan gambut seperti semula, sehingga untuk menanggulanginya perlu adanya pengelolaan secara baik. Pengelolaan tersebut salah satunya yaitu melalui konservasi. Konservasi ini sifatnya eksploitatif yang mempunyai tujuan untuk mempertahankan dan memperbaiki ekosistem. Ekosistem gambut merupakan potensi sumber daya alam yang sangat kaya dengan keanekaragaman hayatinya. Ekosistem gambut mempunyai keberagaman fisik, kimia, biologi dan sangat sensitif serta rapuh terhadap perubahan iklim sehingga pengembangannya baik sebagai fungsi lindung maupun budidaya perlu terus diperbaharui. Ekosistem gambut mempunyai jasa pelayan lingkungan pencegah banjir, kekeringan dan pencemaran disamping menghasilkan berbagai produk atau hasil tanaman, ternak, ikan yang menjadi pangan (food), pakan (feed), papan (fiber), dan obat-obatan.

Indonesia memiliki gambut kurang lebih15,5 - 18,5 juta hektar yang terdapat di 3 pulau besarnya yaitu pulau Sumatera, Kalimantan dan Papua. Kalimantan menjadi pulau dengan sebaran lahan gambut mencapai 9,75 juta ha atau 52\% dari total sebaran lahan gambut yang ada di Indonesia. Dari 9,75 juta lahan gambut yang ada di pulau Kalimantan, Kalimantan Selatan memiliki 1,48 juta ha atau 15,\% sebaran lahan gambut di pulau Kalimantan dan 8\% luasan sebaran gambut Indonesia (Soekardi dan Hidayat, 1988).

Berdasarkan Kepmen LHK No 129 dan 130 Tahun 2017 luas ekosistem gambut di Provinsi Kalimantan Selatan meliputi 102.902,95 hektare, yang terbagi dalam 4 (empat) Kesatuan Hidrologis Gambut (KHG). Kawasan KHG tersebut diatas melintasi daerah kabupaten dari Utara yaitu Kabupaten Tabalong, Balangan, Hulu Sungai Utara (HSU), Hulu Sungai Tengah (HST), Hulu Sungai Selatan (HSS), Tapin terus ke Selatan Kabupaten Banjar dan Barito Kuala. Sebagian melintasi Kabupaten Barito Selatan dan Barito Timur yang berada di Provinsi Kalimantan Tengah. Berdasarkan data dan peta Balai Besar Litbang Sumber Daya Lahan Pertanian (BBSDLP) luas lahan gambut yang berada dalam ekosistem gambut Provinsi Kalimantan Selatan meliputi luas 106.271 hektare (BBSDLP, 2014) atau 107.344 hektare (BBSDLP, 2015). Berdasarkan hasil analisis data dan penyelidikan lapangan dengan skala peta 1:50.000 dihasilkan bahwa ekosistem gambut atau KHG Provinsi Kalimantan Selatan meliputi luas 235.561 hektare. 
Dengan demikian, maka seluruh ekosistem gambut masuk ke dalam kawasan KHG selain berupa tanah gambut, bergambut juga tanah mineral masuk dalam areal KHG

Kerusakan ekosistem gambut (KHG) di Provinsi Kalimantan Selatan akibat kebakaran tahun 2015 mencapai 18.665 hektare atau 13\% dari total seluas 148.194 hektare. Wilayah dengan luas area terbakar terbesar adalah Kab Tapin yang terletak pada KHG Sungai Barito - Sungai Tapin dengan luas 3,900 hektare (3,79\%). Kebakaran lahan gambut selalu berulang dan berdasarkan sebaran titik panas (hot spot) banyak terpusat pada sepanjang kanal-kanal dan daerah konsesi di ekosistem gambut atau KHG Provinsi Kalimantan Selatan. Data terakhir dari Badan Penanggulangan Bencana Daerah (BPBD) Kalimantan Selatan menunjungkkan hingga Sepetember 2017 tercatat kebakaran hutan dan lahan seluas 566 hektare meningkat dibandingkan pada bulan Agustus 2017 hanya sekitar 170 hektar.

Pemanasan global mengakibatkan kenaikan suhu temperature bumi. Perubahan iklim yang terjadi di banyaknya Negara merupakan efek dari kenaikkan temperature yang diakibatkan oleh pemanasan global. Hal ini cukup memberikan pengaruh terhadap banyak sektor dan memiliki kedalaman kompleksitas karena menjangkau didalam berbagai aspek kehidupan manusia. (Chandra et al. 2012)

Karbon dioksida gas 'anthropogenic greenhouse' memiliki kontribusi yang penting dalam menjadi penguat radiasi. Sewaktu masa pra-industrialisasi terjadi kenaikan konsentrasi gas karbon dioksida dari 280 ppm menjadi 379 ppm yang terjadi pada tahun 2005. Kenaikan konsentrasi tertinggi ini terutama berlangsung pada kurun waktu waktu 10 tahun kebelakang yaitu antara tahun 1995 sampai tahun 2005 dengan rata-rata 1,9 ppm per tahun. Peningkatan gas methane di tahun 1990 berkisar dari 715 ppb menjadi 1732 dan di tahun 2005 menjadi 1774 ppb (IPCC, 2007; Kleypas, 1999 ). Pada tahun 2005, kenaikan gas nitrit oksida berkisar dari 270 ppb menjadi 319. Hal ini dikarenakan adanya aktifitas pertanian. (Buddemeier et al., 2004; IPCC, 2007).

Banyak sektor yang terdampak oleh perubahan iklim baik pada sektor ketahanan air, pangan, energy hingga pengaruh terhadap potensi kerusakan keanekaragaman hayati dan ancaman pada bidang-bidang pembangunan lainnya. Hal ini terlihat dari mulai terjadinya kekurangan air pada saat musim kemarau namun mengalami kejadian banjir pada saat musim hujan. Sektor pertanian, perkebunan dan perikanan pun terdampak akibat fenomena perubahan iklim, hal ini karena jadi tidak menentunya musim kemarau dan penghujan mengakibatkan waktu tumbuh dan kembangnya komoditi menjadi terganggu. 
Hal lainnya lagi adalah aspek kesehatan masyarakat, perubahan iklim telah membuat temperature tidak menentu dan mengakibatkan tubuh yang kurang dapat beradaptasi akan mengalami permasalahan kesehatan (Asnawi 2015).

Kejadian kebakaran lahan gambut yang terbakar di Kalimantan Selatan setiap tahunnya selalu terjadi dapat menyebabkan perubahan iklim. Penanganan kebakaran lahan memiliki pola penanganan yang berbeda dan tidak mudah dilakukan ataupun dikelola penganannya, hal ini karena kebakaran lahan gambut tidak terjadi hanya diatas permukaan tanah namun karena sifat sebagai lahan endapan maka kebakaran juga terjadi di dalam tanah. Prosesnya biasanya memang dimulai dari kebakaran yang terjadi di atas permukaan tanah yang kemudian terus merambat ke bagian dalam lahan gambut atau pada area bawah permukaan yang sering disebut dengan ground fire. Gambut yang berasal dari bahan organik akan terus terbakar dan menimbulkan asap putih. Dengan kondisi kebakaran area bawah permukaan maka tidak mudah dilakukan penanganan karena pemadaman harus sampai pada area dalam gambut (assets.wwfid.panda.org, 2016).

\section{METODOLOGI}

Metodologi penelitian ini menggunakan deskriptif kualitatif. Dengan pendekatan literatur review. Literuter review sendiri bertujuan untuk melihat kembali literaturliteratur yang ada baik terkait teori, hasil temuan dan bahan penelitian, direview secara kritis sehingga dapat menjadi landasan kegitan penelitian dan pemikiran dari permasalahan yang akan diteliti

\section{HASIL DAN PEMBAHASAN}

\subsection{Karakteristik Gambut}

Lahan gambut disebut sebagai ekosistem lahan basah, hal ini karena proses pembentukannya dimulai dari endapan bahan organik seperti reruntuhan vegetasi diatas tanah yang terus menumpuk dalam jangka waktu yang panjang sampai ribuan tahun. Akumulasi dari terbentuknya lahan gambut ini disebabkan akibat laju dekomposisi lebih lambat dari laju tumpukan bahan organik yang tertimbun di bawah tanah hutan yang tergolong basah atau tergenang.

Terbentuknya lahan gambut terjadi setelah mengalami beragam tahap-tahap proses lingkungan, pembentukan gambut yang beragam membuat ekosistim gambut mempunyai kondisi kelokalan sendiri atau ciri khas dimasing-masing daerah ekosistemnya. Sehingga perlu pengelolaan yang sesuai dimasing-masing daerah berdasarkan aspek kelokalan dan 
ciri khasnya. Oleh karena itu, perlunya mengetahui kondisi ekosistem gambut sebagai dasar pertimbangan pengelolaan gambut yang komprehensif diantara setiap kawasan hidrologi gambut, tidak terbatas oleh batasan administrasi saja. Ditunjang dengan kajiankajian dan data-data informasi yang valid dan lengkap terkait karakteristiknya sehingga tidak mengakibatkan salah pengelolaan yang berujung pada kerusakan dan pengelolaan yang tidak berkelanjutan.

Karakteristik ekosistem gambut terdiri dari sifat-sifat yang meliputi sifat fisika, sifat kimia, sifat biologi, sifat hidrotopografi, dan jenis sedimen di bawah gambut termasuk antara lain: 1) topografi dan hidrotopografi; 2) air tanah, genangan, atau banjir; 3) tutupan lahan atau pemanfaatan lahan; 4) flora dan fauna yang dilindungi; 5) daya hantar hidrolik; 6) kualitas air; 7) ketebalan, kematangan dan kerapatan lindak; 8) seberapa parah kerusakan lahan gambut; 9) karakteristik substratum di bawah lapisan gambut; dan 10) karakteristik tanah dan kedalaman pirit. Uraian berikut mengemukakan beberapa karakteristik ekosistem gambut Provinsi Kaliamantan Selatan.

Dilihat dari kondisi fisik tanah, lahan gambut termasuk dalam golongan tanah organasol atau tanah histosol, dengan sifat tanah biasanya jenuh air atau terendam sepanjang tahun kecuali telah direkayasa melalui drainase atau yang dilewati oleh sungai. Menurut beberapa ahli, pendefinisian gambut sangat beragam. Berikut ini acuan yang digunakan dalam mendefinisikan gambut meliputi.

- Gambut merupakan tanah yang memiliki kandungan berupa bahan organik $>65 \%$ (beratkering) dan ketebalan gambut $>0.5 \mathrm{~m}$ (Driessen, 1978).

- Gambut merupakan tanah yang terbentuk dari susunan bahan organik dengan ketebalan $>40 \mathrm{~cm}$ atau $60 \mathrm{~cm}$, susunan ini diperoleh dari berat jenis (BD) dan tingkat dekomposisi bahan organiknya (Soil Taxonomy).

Awal terbentuknya gambut diperkirakan sejak zaman glasial akhirya itu sekitar tahun 3.000 hingga 5.000 tahun yang lalu. Pada kondisi tertentu seperti pada lahan gambut dalam memiliki proses hingga 10.000 tahun lama (Brady 1997 dalam Daniel Murdiyarso dkk, 2004 ).

Hardjowigeno (1986) berpendapat bahwa pembentukan dari gambut sendiri akibat adanya penumbukan sisa-sisa tumbuhan yang sudah mati, baik yang telah lapuk ataupun yang belum. Proses dekomposisi yang terhalang dengan kondisi anaerob ataupun lingkungan lainnya yang menyebabkan perkembangan pengurai menjadi menurun sehingga menimbulkan bertambahnya timbunan. Tanah gambut yang terbentuk bisa juga 
disebut dengan proses geogenik dimana terbentuk akibat dari proses deposisi dan transportasi dengan proses pembentukan tanah mineral yang biasanya disebut dengan proses pedogenik.

Berdasarkan lingkungan pembentukannya, ekosistem gambut Provinsi Kalimantan mempunyai karakteristik yang berbeda antara satu tempat atau lokasi dengan lokasi lainnya. Ekosistem gambut Provinsi Kalimantan Selatan berdasarkan proses pembentukannya paling tidak dapat dibedakan antara dua lingkungan pembentukan, yaitu (1) ekosistem pasang surut dan pantai (tidal swamps) dan (2) ekosistem rawa belakang atau rawa lebak (non tidal swamps).

\subsection{Gambut di Kalimantan Selatan}

Rencana Tata Ruang Wilayah Kalimantan Selatan membagi kesatuan fungsi hidrologis terbagi menjadi 4 Kesatuan Hidrologis Gambut (KHG) yaitu Kesatuan Hidrologis Gambut (KHG) Sungai Barito-Sungai Alalak, Kesatuan Hidrologis Gambut (KHG) Sungai Utara-Sungai Serapat, Kesatuan Hidrologis Gambut (KHG) Sungai Balangan - Batangalai dan Kesatuan Hidrologis Gambut (KHG) Sungai Barito-Sungai Tapin. Dengan luas sebaran Kesatuan Hidrologis Gambut (KHG) di Kalimantan Selatan mencapai 340.810 ha dengan prediksi luas Kubah Gambut seluas 86.751 ha

Widjaja Adhi (1991) menyatakan bahwa terdapat 2 kawasan ekosistem lahan gambut yaitu diantaranya kawasan non budidaya dan kawasan budidaya. Kawasan non budidaya dapat dibedakan menjadi dua yaitu yang pertama jalur hijau yang terletak di sepanjang pantai dan tanggul sungai dan yang kedua yaitu tempat tampung hujan yang mencakup area minimal 1/3 dari semua kawasan. Kawasan yang digunakan untuk lahan konservasi yaitu kawasan bagian kubah gambut (peat dome) yang berfungsi menjadi daerah penampungan air hujan. Fungsi Lindung Ekosistem Gambut yaitu sebagai susunan unsur gambut yang mempunyai ciri khusus dan fungsi pokok dalam perlindungan dan keseimbangan tata air, penyimpan cadangan karbon, dan pelestarian keanekaragaman hayati sehingga dapat melestarikan fungsi Ekosistem Gambut. Sedangkan Fungsi Budidaya Ekosistem Gambut merupakan susunan unsur gambut yang mempunyai ciri khusus dan fungsi dalam mendukung produktivitas Ekosistem Gambut dengan kegiatan budidaya berdasarkan dengan daya dukungnya sehingga mampu menambah pelestarian terhadap fungsi Ekosistem Gambut. Berdasarkan peta maka dapat diketahui bahwa mayoritas indikatif fungsi budidaya ekosistem gambut seluas $156.261,18$ ha atau $66 \%$ dari total 
luasan gambut sedangkan luas indikatif fungsi lindung ekosistem gambut seluas 81.549,16 ha atau sekitar 34\%.

Pemanfaatan gambut untuk budidaya pertanian sebenarnya sejak lama oleh masyarakat setempat sebelum ada penetapan peraturan terhadap adanya ketentuanketentuan mengenai fungsi lindung sehingga sebagian ekosistem yang seharusnya masuk dalam fungsi lindung (sekarang) sebagiannya telah dimanfaatkan masyarakat untuk budidaya pertanian dan perkebunan. Oleh karena itu, diperlukan perencanaan perlindungan dan pengelolaan ekosistem gambut yang tepat sesuai fungsi, dengan tetap memperhatikan dan juga mengakomodir berbagai kepentingan dengan mempertimbangkan baik aspek ekonomi, sosial budaya masyarakat, maupun lingkungan hidup dengan prinsif dasar tetap menjamin kelestarian fungsi ekosistem gambut tersebut sehingga dapat menunjang keberlanjutan dan kesinambungan ekosistem maupun kebermanfaatannya untuk kehidupan masyarakat ke depan.

Pada beberapa dekade ini keberadaan hutan di kawasan Kalimantan Selatan semakin terancam akibat kegiatan perambah hutan, para penebang liar dan juga penambang liar. Selain kegiatan illegal di atas, turunnya luasan tutupan hutan/lahan juga dipengaruhi oleh pembangunan sektor perkebunan, sektor kehutanan, dan sektor pertambangan yang memberikan andil bagi turunnya luasan tutupan hutan. Berdasarkan data yang didapat maka total 18.665 ha gambut di Kalimantan Selatan menjadi lokasi pembakaran. Kebakaran ini mengakibatkan dampak-dampak, baik berdampak pada fisik kawasan, dampak ekonomi maupun dampak sosial (LAPAN, 2016). Kebakaran menjadi salah satu penyebab utama rusaknya fungsi ekosistem gambut, dalam enam tahun terakhir tercatat ada 1.053 titik hotspot di area Kawasan Ekosistem Gambut di Kalimantan Selatan. Tahun 2015 menjadi tahun dengan banya ktitik hotspot yang terpantau dengan jumlah mencapai 460 titik hotspot, sedangkan pada tahun 2011 dan 2014 menjadi tahun dengan titik hotspot mencapai dari 200 lebih titik (Dinaskehutanan, 2016). Data dari Badan Penanggulangan Bencana, Hingga September 2017 luas hutan dan lahan yang terbakar mencapai 566,40 hektare atau naik lebih tiga kali lipat dari luas kebakaran hingga Agustus lalu seluas 170 hektare. Sementara sebaran titik api hasil pantauan Satelit Aqua Terra saat ini sebanyak 149 titik api.

Salah satu bencana yang kerap terjadi di Indonesia adalah kebakaran hutan dan lahan. Dampak dari kebakaran hutan dan lahan ini sangatlah banyak, diantaranya rusaknya ekosistem, penurunan keanekaragaman hayati, nilai ekonomi hutan dan produktivitas lahan 
menjadi turun, perubahan iklim mikro maupun global, kesehatan masyarakat terganggu dan tersendatnya semua transportasi baik darat, air maupun udara. Tercatat kebakaran hutan yang paling besar terjadi pada tahun 1997-1998 dan 2006 yang berlokasi di Kalimantan Selatan. Bahkan asap yang dihasilkan dari kebakaran hutan dan lahan sampai berdampak ke berbagai negara tetangga seperti seperti Singapura, Malaysia, dan Thailand. Kondisi dari hutan lahan yang terbakar di Kalimantan Selatan sebagian besar mengandung gambut yang pada dasarnya gambut mudah terbakar. Gambut yang menjadi terbakat merupakan imbas dari pembukaan lahan yang tidak terkendali.

\subsection{Pengelolaan dan Konservasi Lahan Gambut}

Dampak dari kebakaran hutan bagi lingkungan sangatlah besar diantaranya kerusakan ekologi, turunnya keanekaragaman sumber daya hayati beserta ekosistemnya, hingga menurunnya kualitas udara. Tidak hanya bagi lingkungan saja, dampak kebakaran hutan juga menjadikan beberapa aspek menjadi menurun, mulai dari fisik maupun non fisik, secara langsung maupun tidak langsung pada berbagai bidang maupun sektor, skala lokal, nasional, regional, maupun global. Contoh aspek yang mengalami penurunan kualitas yaitu aspek kesehatan yang disebabkan karena penurunan kualitas lingkungan hidup (kesuburan lahan, biodiversitas, pencemaranudara, dst.). Masalah lain yang tidak kalah penting yaitu pemanasan suhu bumi, sedangkan dalam skala regional dan nasional lebih ditingkatkan pada dampak perubahan iklim.

Rencana Restorasi gambut di Provinsi Kalimantan Selatan, dilaksanakan di lokasi lahan gambut yang telah rusak seluas 105.023 hektare yang terbagi di empat kesatuan hidrologis gambut (KHG). Kawasam dari empat KHG ini terdiri dari KHG Sungai BaritoSungai Alalak dengan luas 47.935 hektare dan luas lahan gambut 20.301 hektare. Sebaran lain yaitu KHG Sungai Utar-Sungai Serapat dengan luas 107.737 hektare dan luas lahan gambut 27.176 hektare. Selain itu, restorasi juga dilakukan di KHG Sungai BalanganSungai Batangalai dengan luas 30.859 hektare dan luas lahan gambut 11.008 hektare serta KHG Sungai Barito-Sungai Tapin dengan luas 112.227 hektare dan luas lahan gambut 45.998 hektare (BRG, 2017).

Kurangnya partisipasi masyarakat pada proses perencanaan pengelolaan lahan gambut berdampak pada kurang pekanya program-program rencana terhadap aspek budaya dan kondisi lokal setempat. Perencanaan yang tidak berbasis partisipasi masyarakat membuat tidak dapatnya adaptasi program kegiatan pengelolaan lahan gambut terhadap 
sifat kearifan lokal yang sebenarnya dapat menjadi masukan awal dalam pelaksanaan pengelolaan lahan gambut.

Gambut dengan karakter lahan basah yang sering tergenang membuat secara tidak langsung memiliki system rawa, yang memiliki batasan fisik berupa batasan ekofungsional gambut, Pada ekosistem rawa pantai dan pasang surut, proses pembentukan gambut sangat dipengaruhi oleh adanya dinamika gerakan pasang dan surut yang silih berganti dan kenaikan permukaan air laut (transgression).

Pada ekosistem gambut pasang surut dan pantai ini antara lain yang berada di KHG Sungai Barito seperti di Kab. Banjar dan sebagian Kab. Tapin. Dalam beberapa kasus, lahan gambut pada sistem pulau atau delta ini dimungkinkan membentuk tumpukan seperti kubah atau yang sering disebut kubah gambut memiliki indikasi sistem hidrologis yang khas. Bentuk eksisting kondisi hidrologis yang ada pada kubah gambut ini memiliki peranan yang penting didalam fungsi lingkungan hidup yang didukungnya.

Pada ekosistem rawa lebak, proses pembentukan gambut dipengaruhi oleh dinamika curah hujan dan limpasan banjir sebagai bagian daridaerah aliran sungai (DAS), oleh karenanya diperlukan pengelolaan lahan yang sangat spesifik pada pada subekosistemnya. Ekosistem gambut rawa lebak ini antara lain berada di KHG Sungai Tapin seperti di Kab. Tapin dan KHG S. Balangan- S. Batangalai seperti di Kab. HSU, Kab. HSS, dan Kab. HST.

Bencana kebakaran lahan yang sering terjadi, baik pembakaran yang terjadi karena disengaja ataupun tidak disengaja, membuat lahan gambut ikut terbakar sehingga lapisan gambut menjadi semakin tipis. Bila penipisan lapisan terjadi pada lapisan substratum yang eksistingnya adalah lapisan mineral dan pasir kwarsa, tentunya yang akan terjadi setelah penipisan tersebu adalah berdampak kepada menurun drastisnya kesubutan tanah (Subiksa, Hartatik, dan Agus 2007). Kegiatan mengambil abu sisa pembakaran lahan untuk meningkatkan kesuburan tanah dan pembukaan lahan perkebunan menjadi aktivitas pembakaran terkadang dilakukan, karena menjadi cara pembukaan lahan yang paling murah dan hemat tenaga bagi para pelaku.

Lahan gambut memang lebih rawan terbakar, hal tersebut dikarenakan dari komposisi lahan gambut yang mempunyai kandungan bahan organik yang cukup banyak serta mempunyai sifat kering tak balik, porositas tinggi, dan daya hantar hidrolik vertikal yang rendah. Kebakaran di lahan gambut tidak mudah untuk dikendalikan karena kebakaran tidak hanya melebar keatas dan kesamping namun juga kepermukaan 
bawahtanah. Hal ini mengakibatkan bara api yang sangat sulit dideteksi apakah sudah padam apa belum, sehingga berpotensi terus menyebar kesisi lainnya melalui permukaan bawah tanah tanpa disadari, sehingga air hujan yang lebat menjadi harapan untuk dapat memadamkan bara api yang berada di bawah permukaan. Oeh karena itu, kebakaran di lahan gambut harus dicegah sedini mungkin, penyebab kebakaran lahan gambut biasanya akibat dari pembakaran lahan ataupun bara api kecilpun dapat berpotensi membakar lahan gambut, serta menjaga kondisi kelembaban tanah gambut dengan cara membuat drainase dengan jumlah yang sesuai, karena drainase akan mempercepat lewat (arus) air di lahan gambut (Junaidah 2011) .

Hutan termasuk suatu hal yang sangat penting bagi ekosistem. Hal ini dikarenakan selain fungsinya sebagai penjaga dan penyimpan air, hutan juga memiliki fungsi untuk mencegah terjadinya erosi tanah, mengatur iklim, dan habitat bagi berbagai macam plasma nutfah yang sangat penting untuk perkembangan ilmu pengetahuan dan teknologi. Hutan berdasarkan klasifikasinya terbagi menjadi dua yaitu hutan primer dan hutan sekunder. Hutan primer yaitu hutan yang masih terjaga dan sangat sedikit manusia yang menjamaahnya. Sedangkan hutan sekunder yaitu hutan yang tumbuh dari suksesi sekunder alami di lahan hutan yang telah mengalami gangguan berat seperti lahan bekas pertambangan, peternakan, dan pertanian menetap.

Ekosistem gambut di Provinsi Kalimantan Selatan sebagian besar dinyatakan sebagai fungsi lindung yang diharapkan dapat menyimpan dan mengembangkan berbagai flora dan fauna khas ekosistem gambut. Ekosistem gambut dikenal sebagai kawasan mega biodiversiti dan juga telah ditempati beberapa flora dan fauna yang dilindungi. Hasil inventarisasi pada hutan gambut di Kalimantan dan Sumatera telah ditemukan antara 34-58 jenis pohon sebagai penghasil kayu, dinataranya sudah mulai langka seperti ramin, meranti dan jelutung (Noor, 2001). Menurut laporan Dahuri (1997) dalam hutan primer pada ekosistem gambut sekitar Sungai Mentangai, Kalimantan Tengah telah ditemukan 104 jenis satwa liar terdiri atas 32 jenis mamalia (diantaranya 13 jenis dilindungi); 8 jenis reptil (5 jenis dilindungi); dan 60 jenis burung (19 jenis dilindungi).

Karbon yang tersimpan di dalam hutan dan tanah dibawahnya memiliki total penyimpanan sebesar lebih dari satu triliun ton dengan total yang ada di seluruh dunia. Jumlah itu merupakan dua kali lipat jumlah karbon yang ada di atmosfer atau sama dengan berat +2.000 kali berat keseluruhan atau sama dengan 7 miliar manusia yang berada di dunia, yang dirata-ratakan atau diasumsikan berat rata-rata manusia yaitu $70 \mathrm{~kg}$ per orang. 
Hutan memiliki peran sebagai "penyerap karbon" apabila terjadi peningkatan kepadatan dan luas pada hutan, dikarenakan hutan menyerap karbon yang ada di atmosfer kemudian menyimpannya. Selain itu hutan juga berfungsi sebagai "sumber emisi karbon" dan menyebabkan perubahan iklim, apabila hutan ditebang, kemudian diubah peruntukannya, dan terbakar, maka dapat kita bayangkan seberapa besar karbondioksida yang terbuang dan terlepas kembali ke atmosfer. Oleh karena itu, kondisi tersebut akan membawa dampak perubahan yang besar terhadap sistem cuaca dan iklim di bumi.

Siklus Karbon yang telah dijelaskan dan digambarkan di atas bermula dari melepasnya karbon ke atmosfer yang biasa dikenal sebagai "carbon source" kemudian disimpan dalam tanaman, hewan, sedimen, dan air atau disebut juga "carbon sink". Melalui proses fotosintesis (proses tumbuhan membuat makannanya sendiri untuk menunjang pertumbuhannya dengan bantuan sinar matahari), tumbuhan menangkap karbon dioksida yang berasal dari atmosfer dan menghasilkan oksigen sehingga bisa dihirup oleh manusia dan hewan. Karbon dioksida selanjutnya berubah menjadi senyawa karbon yang merupakan cikal bakal terbentuknya tubuh tanaman, lalu mencadangkan di bagian atas tanah dari tumbuhan (batang, daun, dan organ reproduksi) dan bagian di bawah tanah (akar). Setelah itu, hewan memakan tanaman, menghirup oksigen, dan mengeluarkan karbon dioksida. Kemudian Karbon dioksida yang dikeluarkan oleh hewan tersebut lalu difungsikan untuk tumbuhan dalam melakukan fotosintesis. Menurut Kristensen dkk, 2008 bahwa mikroorganisme dekomposer menjadi pengurai dari karbon yang telah tersimpan dalam tumbuhan yang tidak dimakan oleh hewan (serasah), sehingga membentuk karbon yang dihembusakan ke atmosfer ataupun tertimbun di sedimen mangrove dan terangkut aliran sungai ke arah laut. Berdasarkan siklus karbon yang berada di laut, karbon yang sudah larut difungsikan oleh fitoplankton untuk fotosintesis yang kemudian dihasilkan $\mathrm{C}$ organik. Kondisi ini merupakan salah satu bentuk rantai makanan yang berlangsung di laur. Selanjutnya zooplankton memakan fitopalankton, lalu ikan kecil memakan zooplankton dan ikan-ikan besar memakan ikan kecil.

\subsection{Mitigasi Perubahan Iklim}

Salah satu cara untuk menimalisir jumalah emisi karbon dioksida dan menghambat perubahan iklim yaitu dengan cara mempertahankan keutuhan hutan agar tetap terjaga dan difungsikan dengan baik dan tidak merusak. Persesiaan karbon dalam biomasa hutan berkurang $0.5 \mathrm{Gt}$ di setiap tahunnya dalam kurun waktu antara tahun 2005 sampai tahun 2010 diakibatkan oleh berkurangnya luasan pada hutan diantaranya karena proses 
deforestasi (FAO 2010). Deforestasi yang terdapat di beberapa penjuru dunia memberikan kontribusi $12-17 \%$ emisi karbon dioksida secara global di tiap tahunnya. Apabila hutan hilang maka yang akan terjadi adalah memperparah perubahan iklim yang dikarenakan hilangnya fungsi penyerapan hutan sehingga karbon yang tersimpan di dalam tanah dan tumbuhan akan dilepaskan lagi ke atmosfer.

Fungsi hutan yang sebenarnya dapat dimanfaatkan dalam mengatasi perubahan iklim yang tidak hanya menyerap gas rumah kaca yang terdapat di atmosfer. Peran penting yang dimiliki hutan yaitu dalam menjaga tutupan awan, mengembalikan kembali sinar matahari yang telah ke bumi untuk dikembalikan keluar atmosfer, berkontribusi dalam proses berubahnya air menjadi uap dan menambah kelembaban di atmosfer yang kemudian mampu membuat sejuk udara. Setelah itu, hutan dapat membantu menyesuaikan mata pencaharian manusia yang diakibatkan adanya perubahan iklim dengan cara menyediakan fungsi-fungsi lingkungan sehingga dapat memenuhi kebutuhan. Hutan menjadi prioritas penting bagi lebih dari 1,6 milyar orang di seluruh dunai dalam memenuhi gizi dan penghasilan pada waktu terjadinya tekanan iklim dan gagal.

Wilayah Kalimantan Selatan umumya memiliki dua musim antara lain yaitu musim hujan dan musim kemarau (panas). Periode musim hujan umumnya antara bulan Oktober hingga Mei, selama musim hujan berlangsung angin bertiup dari arah Timur Laut yaitu pada setiap bulannya kecepatann angin sekitar antara 8-14 knot serta rata-rata tiap bulan antara 5-6 knot. Sementara pada musim kemarau (panas) umumnya antara bulan Juni hingga bulan Agustus dan di sela-sela kedua musim tersebut terdapat musim pancaroba. Seperti beberapa daerah di Indonesia, Provinsi Kalimantan Selatan memiliki temperatur udara maksimum berkisar antara $33,1^{\circ} \mathrm{C}-35^{\circ} \mathrm{C}$, temperatur udara minimum berkisar antara $22,6^{\circ} \mathrm{C}-23,8^{\circ} \mathrm{C}$ dengan temperatur rata-rata dikisaran antara $15,6^{\circ} \mathrm{C}$ sampai $26,9^{\circ} \mathrm{C}$ sedangkan kelembaban rata-rata dikisaran antara 77\%-91\%. Rata-rata intensitas penyinaran matahari di Provinsi Kalimantan Selatan yaitu sebanyak 52,5\% dengan kenaikan curah hujan tertinggi terjadi di bulan Maret yaitu sebesar 426,0 $\mathrm{mm}$ dan penurunan curah hujan terendahsebesar 75,0 mm pada bulan September.

Berdasarkan penelitian alamiah ekosistem dapat memberikan jasa atau fungsi sebagai pengaturan iklim mikro berupa pengaturan curah hujan, suhu, ikim, angin, dan kelembapan, pengendali gas rumah kaca, dan dapat berfungsi sebagai penyerap karbon. Fungsi dari pengaturan iklim diakibatkan dari adanya faktor biotik khususnya vegetasi atau tumbuhan, serta letak dan faktor fisiografis seperti topografi dan bentuk lahan. Kawasan 
yang memiliki kerapatan vegetasi yang tinggi dan terletak di ketinggian yang besar seperti pegunungan akan mempunyai sistem pengaturan iklim yang lebih baik yang berfungsi langsung pada pengurangan emisi karbon diokasida dan efek rumah kaca dan mengurangi dampak pemanasan global seperti meningkatnya permukaan laut dan perubahan iklim yang tidak terkendali dan gelombang panas.

Ekoregion pegunungan serta perbukitan Struktural Kompleks Meratus memiliki potensi yang besar untuk pengaturan iklim (26,73\% dan 12,06\%). Pegunungan Struktural didominasi oleh penggunaan lahan hutan, yang mana sebagai yang menghasilkan oksigen. Penggunaan lahan dan ketinggian tempat menyebabkan udara di wilayah pegunungan dan perbukitan udaranya menjadi sejuk dan lebih bersih. Hutan juga berfungsi sebagai alat penyaring alami bagi polusi udara yang dikeluarkan dari kegiatan manusia. Dataran fluvial yang berfungsi sebagai lahan sawah juga memiliki potensi sangat baik untuk mengatur iklim. Dari hasil proses fotosintesis, tumbuh-tumbuhan ataupun lahan pertanian memproduksi oksigen yang membuat udara menjadi sejuk. Perbukitan dengan penggunaan lahan ladang mempunyai potensi sedang. Hal ini dikarenakan tempat yang mempunyai tingkat kerapatan vegetasi yang rendah dan ketinggian tempat mengakibatkan potensi yang dimiliki tidak sebagus kawasan hutan. Penggunaan lahan semak belukar di berbagai ekoregion mempunyai potensi rendah untuk mengatur iklim. Kerapatan vegetasi relatif renggang, luas tajuk pohon yang tidak terlalu lebar dan ketinggian tempat rendah mengakibatkan oksigen yang diproduksi relative sedikit. Untuk itu kelestarian hutan mutlak diperlukan.

Pengaturan iklim mikro, yang terdiri dari pengaturan suhu, kelembaban dan hujan, angin, pengendalian gas rumah kaca, dan penyerapan karbon. Kalimantan Selatan dapat diketahui bahwa fisik hutan kawasan Kalimantan Selatan mempunyai kemampung yang sedang dan tinggi dalam menjaga perubahan iklim sehingga perlu perlindungan pada kawasan hutan Kalimantan Selatan.

Salah satu fungsi hutan tropis yaitu mempunyai kemampuan sebagai tempat penyimpan karbon di tanah serta pepohonan. Hutan tropis memiliki sifat seperti spons/busa yang mampu menyerap karbon dioksida yang berasal dari pembakaran bahan bakar fosil yang dijadikan sebagai sumber energi. Manusia memerlukan hutan yang sangat luas untuk 'mencegah' dan memerangi perubahan iklim untuk menjaga bumi. Namun kenyataannya berbeda, manusia merusak hutan. Kerusakan hutan memberika 20\% dari emisi GRK tiap tahunnya. Selain itu, masih banyak lagi emisi yang diproduksi dari semua tempat di 
seluruh dunia seperti emisi yang dihasilkan dari mobil, truk, kereta, kapal dan pesawat pada tahun 2004. Kondisi hutan rawa gambut di Indonesia sudah musnah yang diakibatkan dari pembalakan, pengeringan kemudian di bakar guna perluasan kelapa sawit. Padahal lahan gambut (kadang-kadang hingga kedalaman 12 meter) menyimpan karbon yang sangat besar. Maka pada saat gambut dikeringakan lalu dibakar akan membuat suatu boom karbon yang mampu melepaskan +2 milliyar ton karbon dioksida berbahaya di tiap tahunnya. Akibat dari eksploitasi hutan dan lahan gambut, menyebabkan Indonesia menjadi negara ketiga sebagai negara pencemar polusi udara ketiga di dunia setelah Amerika dan Cina. Emisi yang dihasilkan oleh Indonesia adalah 85\% yang bersumber dari perusakan hutan dan konversi lahan gambut.

Kenaikan kecil suhu masih bisa ditanggulangi secara alamiah oleh hutan. Tapi periode kemarau panjang yang makin sering, menjadi ancaman bahaya besar. Secara alami, unsur-unsur hara yang diperlukan tumbuh-tumbuhan diperoleh dari ekosistem yang melewati serapan haranya untuk selanjutnya dikumpulkan di jaringan tumbuh-tumbuhan tersebut lalu kembali lagi ke tanah dengan secara langsung maupun tidak langsung sebagai bahan organik. Proses ini di tiap-tiap tumbuhan berbeda-beda, karena hal ini dipengaruhi oleh kondisi tumbuhan, iklim dan jenis tanahnya yang kemudian berdampak pada tingkat suburnya tanah dan tingkat produksi pertanian yang tinggi. Untuk memproduksi bahan organik diperlukan hara baik tingkat trofik produser maupun konsumer yang biasanya terletak dalam lingkungan abiotik dengan konsentrasi yang lebih rendah dari pada yang dibutuhkan untuk aktivitas pertumbuhan. Walaupun demikian, organisme yang berada di ekosistem tua seperti hutan yang isinya hara dalam konsentrasi dengan jumlah yang besar dan memiliki nilai tinggi. Hilangnya hutan menyebabkan peningkatan suhu diurnal variasi di daerah deforestasi, yang cenderung mengarah pada kenaikan suhu udara rata-rata dan maksimal. Hal ini juga menyebabkan sejumlah besar pemanasan, bila dibandingkan dengan emisi karbon dioksida dari perubahan penggunaan lahan

Seiring dengan semakin terbukanya ekosistem gambut untuk pengembangan pertanian dan perkebunan, maka keanekaragaman flora dan fauna tersebut di atas sudah banyak berkurang atau hilang. Hasil survei (quick assessment) menunjukkan pada ekosistem gambut Provinsi Kalimantan Selatan tidak ditemukan lagi flora atau fauna khas yang harus dilindungi khususnya pada kawasan yang sudah terbuka. Tutupan lahan pada ekosistem gambut Provinsi Kalimantan Selatan menunjukkan sebagian besar berupa semak-belukar, disusul pertanian lahan kering, atau lahan kering bercampur semak, dan 
perkebunan. Hal ini menunjukkan menurunnya keanekaragaman hayati dan terjadinya proses untuk menjadi kawasan monoculture.

Ketebalan gambut, kematangan dan kerapatan lindak (bulk density) mempunyai korelasi yang kuat. Ketebalan gambut dibedakan disebut gambut dangka/tipisl apabila mempunyai lapisan gambut 0,5-1,0 m, gambut sedang apabila lapisan gambut 1-2 m, gambut dalam/tebal apabila lapisan gambut 2-3 m, dan gambut sangat dalam/sangat tebal apabila lapisan gambut $>3 \mathrm{~m}$. Ekosistem gambut tebal umumnya mempunyai kematangan fibrik artinya dekompsisi masih belum sempurna, gambut tipis sampai sedang mempunyai kematangan hemik sampai saprik artinya sebagian gambut sudah mengalami dekomposisi lanjut.

Kerapatan lindak mempunyai hubungan dengan kematangan gambut. Kerapatan lindak (KL) tanah gambut antara 0,01 - 0,2 g/cm3, tergantung pada tingkat kematangan. KL untuk gambut fibrik sampai hemik berkisar 0,05-0,15 g/cm3 lebih kecil dari gambut hemik sampai saprik berkisar 0,10-0,30 g/cm3 (Noor, 2001). Kadar lengan (KL) tanah gambut yang sudah lama dibudidayakan lebih tinggi karena selain terjadi perubahan kematangan juga sudah banyak percampuran dengan bahan mineral tanah. Nilai praktis kerapatan lindak berkaitan dengan porositas tanah, sedangkan kematangan berkaitan dengan penyiapan lahan atau pengolahan tanah serta opersional alat mesin pertanian dan pendirian bangunan.

Tabel 1. Sebaran Gambut Berdasarkan Ketebalannya perKHG Kalimantan Selatan

\begin{tabular}{|l|l|c|c|c|c|c|c|}
\hline \multirow{2}{*}{ No } & \multirow{2}{*}{ Nama KHG } & \multirow{2}{*}{ Mineral } & \multicolumn{5}{|c|}{ Ketebalan gambut (meter) } \\
\cline { 4 - 8 } & & & $<\mathbf{0 , 5}$ & $\mathbf{0 , 5}-\mathbf{1}$ & $\mathbf{1 - 2}$ & $\mathbf{2 - 3}$ & $>\mathbf{3}$ \\
\hline 1 & S Bal -S Bt Alai & 17.423 & 16 & 176 & 1,948 & 9,651 & 1,60 \\
\hline 2 & S Barito - S Alalak & 42.430 & 3,609 & 1,786 & 0 & 0 & 0 \\
\hline 3 & S.Barito - S. Tapin & 98.931 & 3,757 & 9,036 & 242 & 0 & 0 \\
\hline 4 & Si Utar -S Serapat & 29.061 & 1,182 & 104 & 7,762 & 4,652 & 2,21 \\
\hline & Total & $\mathbf{1 8 7 . 8 4 5}$ & $\mathbf{8 . 5 6 4}$ & $\mathbf{1 1 . 1 0 2}$ & $\mathbf{9 . 9 5 2}$ & $\mathbf{1 4 . 0 3}$ & $\mathbf{3 . 8 0}$ \\
\hline
\end{tabular}

Berdasarkan tabel di atas diperoleh bahwa keberadaan gambut tebal semakin menipis oleh karenanya perlu adanya siasat atau strategi mitigasi dan pengadaptasian guna menyelamatkan keanekaragaman hayati khususnya lahan gambut yang harus dilaksanakan oleh seluruh pihak. Salah satu kunci keberhasilan upaya ini adalah membudayakan kearifan manusia yang menekankan pada pengelolaan kesadaran diri untuk hidup berdampingan dengan ekosistem secara seimbang yaitu melalui pemeliharaan ekosistem alamiah, perlindungan dan peningkatan daya dukung ekosistem, pengelolaan habitat untuk 
berbagai spesies yang terancam punah, menciptakan wadah perlindungan serta daerahdaerah penyangga dan pembentukan jaringan kawasan perlindungan baik darat, air maupun laut dengan memperhitungkan estimasi ataupun ramalan perubahan iklim.

Kerusakan gambut yang tidak ditangani akan mengakibatkan berkurangnya jumlah gambut di Kalimantan Selatan. Hal ini dibuktikan bahwa semakin menipisnya gambut dari tiap tahunnya. Jika jumlah gambut semakin berkurang, maka akibatnya adalah terjadinya perubahan iklim yang tidak terkendali. Kegiatan pengelolaan dan konservasi gambut diharapkan mampu mengurangi kerusakan gambut di Kalimantan Selatan. Kegiatan ini tidak hanya dilakukan oleh pemerintah setempat melainkan membutuhkan partisipasi masyarakat.

\section{KESIMPULAN DAN SARAN 4.1. Kesimpulan}

Beberapa upaya yang bisa dilakukan sebagai upaya untuk pengelolaan ekosistem gambut sehingga berkelanjutan, dapat dilakukan dengan berbagai upaya, yaitu:

1. Adaptasi perubahan iklim melalui peningkatan ketahanan ekosistem gambut dari dampak perubahan iklim pada ekosistem gambut dengan fungsi budidaya.

2. Pemeliharaan dan pencadangan ekosistem gambut sebagai pengendali dampak perubahan iklim.

3. Pengembangan kebijakan pemanfaatan ekosistem gambut berkelanjutan.

4. Melakukan upaya peningkatan pemanfaatan fungsi ekosistem gambut dengan pemilihan jenis-jenis tanaman asli dan produk turunannya di ekosistem gambut.

5. Partisipasi masyarakat dalam program kegiatan pengelolaan lahan gambut terhadap sifat kearifan lokal.

\subsection{Saran}

Dari berbagai permasalahan yang ada dalam pengelolaan ekosistem gambut dan rencana yang perlu dilakukan, maka ada beberapa rekomendasi yang perlu dilakukan sebagai upaya untuk pemeliharaan kawasan lahan gambut antara lain:

1. Mempertahankan ekosistem gambut yang masih dalam kondisi alami

2. Konservasi fungsi hidrologis gambut, pelestarian keanekaragaman hayati, dan pemanfaatan ekosistem gambut secara optimal.

3. Melibatkan masyarakat dalam melakukan konservasi sehingga optimal dalam melakukan kegiatan-kegiatan pengelolaan lahan gambut. 
4. Pemantauan tinggi muka air tanah di lahan gambut dan penurunan permukaan tanah pada titik penaatan yang telah ditetapkan.

5. Peningkatan pemanfaatan fungsi Ekosistem Gambut dengan pemilihan jenis-jenis tanaman asli dan produk turunannya di Ekosistem Gambut.

6. Mempertahankan keutuhan hutan agar tetap terjaga dan difungsikan dengan baik sehingga meminimalisir adanya emisi karbon dioksida dan menghambat perubahan iklim.

\section{DAFTAR PUSTAKA}

Asnawi, Robert. (2015). "Perubahan Iklim Dan Kedaulatan Pangan Di Indonesia.Tinjauan Produksi Dan Kemiskinan.” Sosio Informa 1(3): 293-309

Buddemeier RW, Kleypas JA and Aronson R., 2004. Coral Reefs and Global Climate Change: Potential Contributions of Climate Change to Stresses on Coral Reef Ecosystems. Prepared for the Pew Center on Global Climate Change.

Chandra, Tezario et al. (2012). "Dampak Perubahan Iklim Terhadap Sektor Perikanan Di Desa Sungai Kakap Estimasi Tingkat Kesejahteraan Nelayan Di Desa Sungai Kakap Berdasarkan Nilai Tukar Nelayan.” Jurnal Mahasiswa Teknik Lingkungan UNTAN 1(1): 1-10.

Dahuri, R. (1997). Pengembangan rencana pengelolaan pemanfaatan berganda ekosistem mangrove di Sumatera. Dalam Panduan Pelatihan Pelestarian dan Pengembangan Ekosistem Mangrove Secara Terpadu dan Berkelanjutan, Pusat Penelitian Lingkungan Hidup Universitas Brawijaya, Malang.

Driessen, F. M. (1978). Inactivation of native milk proteinase by heat treatment. Netherlands Milk and Dairy Journal.

Junaidah. (2011). "Lahan Gambut Sebagai Sumber Emisi Gas Rumah Kaca Dan Upaya Mitigasinya." Galam 5(1): 13-33

Fact Gambut http://assets.wwfid.panda.org/downloads/faqgambut.pdf. diakses pada 0902-2019

Kleypas, J. A., Buddemeier, R. W., Archer, D., Gattuso, J. P., Langdon, C., \& Opdyke, B. N. (1999). Geochemical consequences of increased atmospheric carbon dioxide on coral reefs. science, 284(5411), 118-120.

Noor, M. (2001). Pertanian Lahan Gambut, Potensi dan Kendala. Kanisius. 
IPCC. (2007). Climate Change: the physical science basis. Summary for policymakers. Contribution of Working Group I to the Fourth Assessment Report of the Intergovernmental Panel on Climate Change., WMO-UNEP.

Undang-Undang Nomor 32 (2009) tentang Perlindungan dan Pengelolaan Lingkungan Hidup.

Peraturan Menteri Lingkungan Hidup dan Kehutanan Nomor P.12/MENLHK-II/2015 junc-to (2015) Peraturan Menteri Lingkungan Hidup dan Kehutanan Nomor P.17/MENLHK/SETJEN/KUM.1/2/2017 tentang Pembangunan Hutan Tanaman Industri.

Kementerian Pertanian (Kementan) (2011). Pengelolaan Lahan Gambut Berkelanjutan. Policy Brief. ICCTF-Badan Litbang Pertanian. Jakarta. 13 hlm.

Kementerian Pertanian (Kementan). 2014a. Panduan Pengelolaan Berkelanjutan Lahan Gambut Terdegradasi. Neneng L. Nurida dan Wihardjaka (editor). Badan Litbang Pertanian. Jakarta. 64 Hlm.

Keputusan Menteri Lingkungan Hidup dan Kehutanan Nomor SK.129/MENLHK/SETJEN/PKL.0/2/2017 tentang Penetapan Peta Kesatuan Hidrologis Gambut;

Keputusan Menteri Lingkungan Hidup dan Kehutanan Nomor SK.130/MENLHK/SETJEN/PKL.0/2/2017 tentang Penetapan Peta Fungsi Ekosistem Gambut .

Prasetyo, B. H., Janssen, J.A.M, Alkasuml. (1990). Lanscape and soil genesis in Pulau Petak, Kalimantan. Dalam Workshop on Acid Sulphate Soils in The Humid Tropics. AARD LAWOO Bogor

Subiksa, I. G. M., Ardi, D., \& Adhi, I. W. (1991). Pembandingan pengaruh P-alam dan TSP pada tanah sulfat masam (Typic Sulfaquent) Karang Agung Ulu Sumatera Selatan. Prosiding Pertemuan Pembahasan Hasil Penelitian Tanah, 3-5.

Subiksa, I. G. M., \& Adhi, I. W. (1998). Pembandingan pengaruh bahan amelioran untuk meningkatkan produktivitas lahan gambut. Dalam Prosiding Pertemuan Pembahasan dan Komunikasi Hasil Penelitian Tanah dan Agroklimat.

Subiksa, I. G. M., W. Hartatik, and F Agus. (2007). Pengelolaan Lahan Gambut Secara Berkelanjutan. Bogor: Balai Penelitian Tanah. Balai Besar Penelitian dan Pengembangan Sumberdaya Lahan Pertanian. Badan Litbang Pertanian. Kementerian Pertanian. 
Soekardi, M., \& Hidayat, A. (1988). Extent and Distribution of Peat Soils of Indonesia. dalam: paper presented at Third Meeting of the Cooperative Research on Problem Soils.

Tomich, T. P., Chomitz, K., Francisco, H., Izac, A. M. N., Murdiyarso, D., Ratner, B. D., \& Van Noordwijk, M. (2004). Policy analysis and environmental problems at different scales: asking the right questions. Agriculture, Ecosystems \& Environment, 104(1), 5-18.

Widjaja-Adhi, I. P. G. (1997). Developing tropical peatlands for agriculture. JO Rieley and SE Page, 45-54. 